\title{
FASILITAS DAN LOKASI TERHADAP KEPUTUSAN KONSUMEN MENGINAP DI GRAND Q HOTEL KOTA GORONTALO
}

\author{
Hapsawati Taan ${ }^{1}$ \\ Zulfia K. Abdussamad ${ }^{2}$ \\ Indra Palangka ${ }^{3}$ \\ Jurusan Manajemen, Fakultas Ekonomi, \\ Universitas Negeri Gorontalo, Indonesia \\ hapsataan@yahoo.co.id \\ mailto:zulfia.libra@gmail.com
}

\begin{abstract}
The purpose of this study was to determine and test the effect of facilities and location on the decision to stay at the Grand Q Hotel Gorontalo City. The type of research method used in this study is quantitative research. Population unknown in exact numbers (infinity). The use of the selected sample technique is sampling Accidental Sampling. Methods of data collection using a questionnaire as many as 96 respondents. Data analysis techniques used multiple linear regression analysis. The results showed that the facilities had a positive and significant effect on the decision to stay overnight. While the location has a positive but not significant effect on the decision to stay at the Grand Q Hotel Gorontalo City. Suggestions that hotel management should always pay attention to hotel facilities because some visitors feel that the facilities available still need to be improved and improved, as well as the importance of a large parking location.
\end{abstract}

Keywords: Facilities, Location, Hotel

\begin{abstract}
Abstrak
Tujuan dalam penelitian ini adalah untuk mengetahui dan menguji pengaruh fasilitas dan lokasi terhadap keputusan menginap di Grand Q Hotel Kota Gorontalo. Metode penelitian jenis penelitian yang digunakan dalam penelitian ini adalah jenis penelitian kuantitatif. Populasi tidak diketahui dalam jumlah yang pasti (infinity). Penggunaan teknik sampel yang di pilih adalah penarikan sampel Accidental Sampling. Metode Pengumpulan data menggunakan kuesioner jumlah sebanyak 96 responden. Teknik analisis data menggunakan analisis regresi linear berganda. Hasil penelitian menunjukkan bahwa fasilitas berpengaruh positif dan signifikan terhadap keputusan menginap. Sedangkan lokasi berpengaruh positif namun tidak signifikan terhadap keputusan menginap di Grand Q Hotel Kota Gorontalo. Saran sebaiknya manajemen hotel senantiasa memperhatikan fasilitas hotel karena sebagian pengunjung merasakan bahwa fasilitas yang tersedia masih perlu ditingkatkan dan diperbaiki, serta pentingnya lokasi parkir yang luas.
\end{abstract}

Kata Kunci: Fasilitas, Lokasi, Hotel 


\section{PENDAHULUAN}

\section{Latar Belakang Masalah}

Zaman globalisasi seperti ini persaingan bisnis harus transparan dan konsisten dalam memenuhi kebutuhan konsumennya, disamping mereka juga harus berlomba dengan pesaing untuk mempertahankan citra terhadap konsumennya. Salah satunya di industri jasa menyatakan dampak globalisasi menyebabkan industri jasa yang terdiri dari berbagai macam industri seperti industri telekomunikasi, transportasi, perbankan, dan perhotelan berkembang dengan cepat. Dalam penelitian ini akan membahas mengenai bagaimana industri perhotelan lokal yaitu Grand Q Hotel kota Gorontalo dalam menarik minat konsumennya. Fasilitas merupakan segala sesuatu yang sengaja disediakan oleh penyedia jasa untuk dipakai serta dinikmati oleh konsumen yang bertujuan memberikan tingkat kepuasan yang maksimal.Fasilitas merupakan segala sesuatu yang bersifat peralatan fisik yang disediakan oleh pihak penjual jasa untuk mendukung kenyamanan konsumen (Kotler dan Keller 2016). Lokasi merupakan salah satu faktor dari situasional yang ikut berpengaruh pada keputusan pembelian.Dalam konsep pemasaran terdapat istilah yang dikenal dengan marketing mix atau bauran pemasaran yang terdiri dari produk, harga, promosi dan lokasi usaha.

Hotel pada umumnya menyediakan harga yang terjangkau bagi konsumen, tetapi harga juga tidak bisa menjadi faktor penentu konsumen dalam menentukan pilihan untuk menginap, namun fasilitas bisa menjadi pertimbangan karena mempunyai produk berupa fasilitas utama sebagai produk jasa yaitu kamar, ataupun fasilitas pendukung seperti kolam renang, restoran, laundry dan lain-lain. Permasalahan tersebut maka penting bagi pihak Grand $Q$ hotel untuk memperhatikan apa yang di butuhkan oleh seorang konsumen, hal tersebut karena konsumen adalah orang yang melakukan pembelian suatu produk/jasa dan melakukan interaksi pada periode waktu tertentu untuk memenuhi kebutuhannya.

Identifikasi pada faktor lokasi menunjukan bahwa konsumen Grand Q Hotel Kota Gorontalo merasakan bahwa lokasi dari hotel berada pada lokasi yang strategis karena di pusat Kota dan dekat dengan berbagai instansi dan pusat perbelanjaan. Meski demikian, sebagian besar konsumen merasakan bahwa Grand $Q$ Hotel kurang representatif untuk lokasi parkirnya, selain karena jalan menuju parkir yang curam dan juga pengunjung yang akan parkir di jalan depan hotel akan mengganggu lalu lintas. Penelitian terdahulu telah menganalisis pokok masalah tentang faktor-faktor yang mempengaruhi keputusan menginap. Secara umum, dari beberapa penelitian tersebut telah memberikan gambaran bahwa fasilitas dan lokasi sudah pasti memberikan pengaruh terhadap keputusan menginap. Peneliti mencoba membandingkan titik perbedaan penelitian ini seperti penelitian Caesari, Dkk (2015) memiliki perbedaan yaitu dimana penelitian menggunakan lima variabel dan menggunakan teknik analisis Regresi Berganda(Multiple Regresion) dengan teknik pengambilan sampel menggunakan teknik Probability Sampling Dan Insidental Sampling sementara peneliti menggunakan tiga variabel dengan menggunakan analisis Regresi berganda dan teknik penentuan sampel Accidental Samplingyaitu teknik penentuan sampel berdasarkan kebetulan, dalam pengujian penelitian ini

Tujuan dalam penelitian ini adalah 1) Untuk mengetahui dan menguji pengaruh fasilitas terhadap keputusan menginap di Grand Q Hotel. 2) Untuk mengetahui dan menguji pengaruh lokasi terhadap keputusan menginap di Grand Q Hotel Gorontalo 3) Untuk mengetahui dan menguji pengaruh secara simultan fasilitas dan lokasi terhadap keputusan menginap di Grand Q Hotel Kota Gorontalo. 


\section{A. Tinjauan Teoritis}

\section{Faktor-Faktor Yang Mempengaruhi Desain Fasilitas}

Menurut Tjiptono (2015:119), faktor-faktor yang berpengaruh terhadap keputusan desain fasilitas yaitu:1) sifat dan tujuan organisasi; sifat dan tujuan seringkali menentukan berbagai ketentuan desainnya. 2) ketersediaan tanah dan kebutuhan akan ruang dan tempat setiap perusahaan membutuhkan lokasi fisik untuk mendirikan fasilitas jasanya 3) Fleksibilitas Fleksibilitas desain sangat dibutuhkan apabila volume permintaan sering berubah, sehingga resiko keusangan relative besar. 4) Faktor Estetis, Fasilitas yang tertata rapi, menarik, dan estetis akan dapar meningkatkan sikap positif pelanggan. 5) Masyarakat dan lingkungan sekitar masyarakat dan lingkungan sekitar memainkan peran penting dan berpengaruh besar terhadap perusahaan. 6) Biaya kontruksi dan operasi, biaya kontruksi dipengaruhi oleh jumlah dan jenis bahan bangunan yang digunakan.

\section{Indikator Fasilitas}

Menurut Tjiptono, (2015:318) setidaknya terdapat enam faktor, yaitu: 1) Perencanaan spasial, seperti proporsi,simetri,tekstur dan warna perlu diintregasikan dan dirancang secara cermat untuk menstimulasi respon intelektua dan respon emosional dari pemakai. 2) Perencanaan ruangan, mencakup perancangan interior dan arsitekstur, seperti penempatan perabotan dan perlengkapannya dalam ruanga, desain aliran sirkulasi dan lain-lain. 3) Perlengkapan/perabotan, berfungsi sebagai sarana yang memberikan kenyamanan, sebagai pajangan atau infastruktur pendukung bagi penggunaan barang para pelanggan. 4) Tata cahaya dan warna, adalah warna jenis pewarnaan ruangan atau pengaturan pencahayaan sesuai sifat aktivitas yang dilakukan dalam ruangan serta suasana yang diinginkan. 5) Pesan-pesan grafis, adalah penampilan visual, penempatan, pemilihan bentuk fisik, pemilihan warna. 6) Unsur pendukung, Keberadaan fasilitas utama tidak akan lengkap tanpa adanya fasilitas pendukung lainnya, seperti: tempat ibadah, toilet, tempat parkir, dan internet.

\section{Pemilihan dan Indikator Lokasi}

Faktor kunci dalam memilih lokasi yang idel menurut Mimi (2015:93) adalah sebagai berikut: 1)Tersedianya sumber daya. Tersedianya sumber daya, terutama bahan mentah sebagai bahan baku produksi, tenaga kerja, dan sarana transfortasi akan membantu pengusaha dalam banyak hal. 2) Pilihan pribadi wirausahawan.3) Pertimbangan gaya hidup dengan fokus untuk semata-mata lebih mementingkan keharmonisan keluarga daripada kepentingan bisnis. 4) Kemudahan dalam mencapai konsumen berorientasi pada pasar (pusat konsentrasi para konsumen berada). Indikator Lokasi menurut Hendra (2013:276) variabel lokasi memakai indikator sebagaiberikut: 1) Lokasi mudah dijangkau 2) Ketersediaan lahan parkir 3) Memiliki tempat yang cukup luas 4) Lingkungan sekitar yang nyaman.

\section{Keputusan Menginap}

Perusahaan hendaknya memperhatikan aspek-aspek perilaku konsumen seperti siapa yang akan membeli (who), apa yang dibeli (what), mengapa membeli produk atau jasa tersebut (why), kapan membeli (when), dimana membelinya (Where), bagaimana proses keputusan menginapnya (how), berapa sering atau menggunakan produk/jasa (how often), agar perusahaan dapat mengetahui 
keinginan konsumen sehingga konsumen bersedia untuk melakukan pembelian produk/jasa tersebut (Tjiptono, 2014).

\section{Indikator Keputusan Menginap}

Menurut Tjiptono (2014 : 43) lima indikator keputusan menginap: 1) Emosi dan mood pelanggan mempengaruhi evaluasi pelanggan bersangkutan terhadap service encounter. 2) Dramaturgi, Konsep dramaturgi yang banyak digunakan dalam sosiologi dalam konteks pemasaran jasa. 3) Peran (role) dan script theory, Peran (role) adalah serangkaian pola perilaku yang dipelajari melalui pengalaman dan komunikasi, yang akan dilakukan oleh individu tertentu dalam interaksi sosial. 4). Control theory, adalah memberdayakan atau memberikan tingkat kendali tertentu kepada pelanggan, supaya mereka merasa yakin atas apa yang mereka lakukan dan beli. 5). Costumer compitability, peran pelanggan lain yang menerima jasa pada saat bersamaan juga tidak kalah pentingnya dalam menentukan pengalaman jasa keseluruhan pelanggan tertentu.

Berdasarkan penelitian terdahulu dan menganalisis pokok masalah tentang faktor-faktor yang mempengaruhi keputusan menginap di hotel. Secara umum, dari beberapa penelitian tersebut telah memberikan gambaran bahwa fasilitas dan lokasi memberikan pengaruh terhadap keputusan menginap. Berdasarkan rumusan masalah, kerangka pemikiran penelitian seperti pada gambar 1 sebagai berikut:

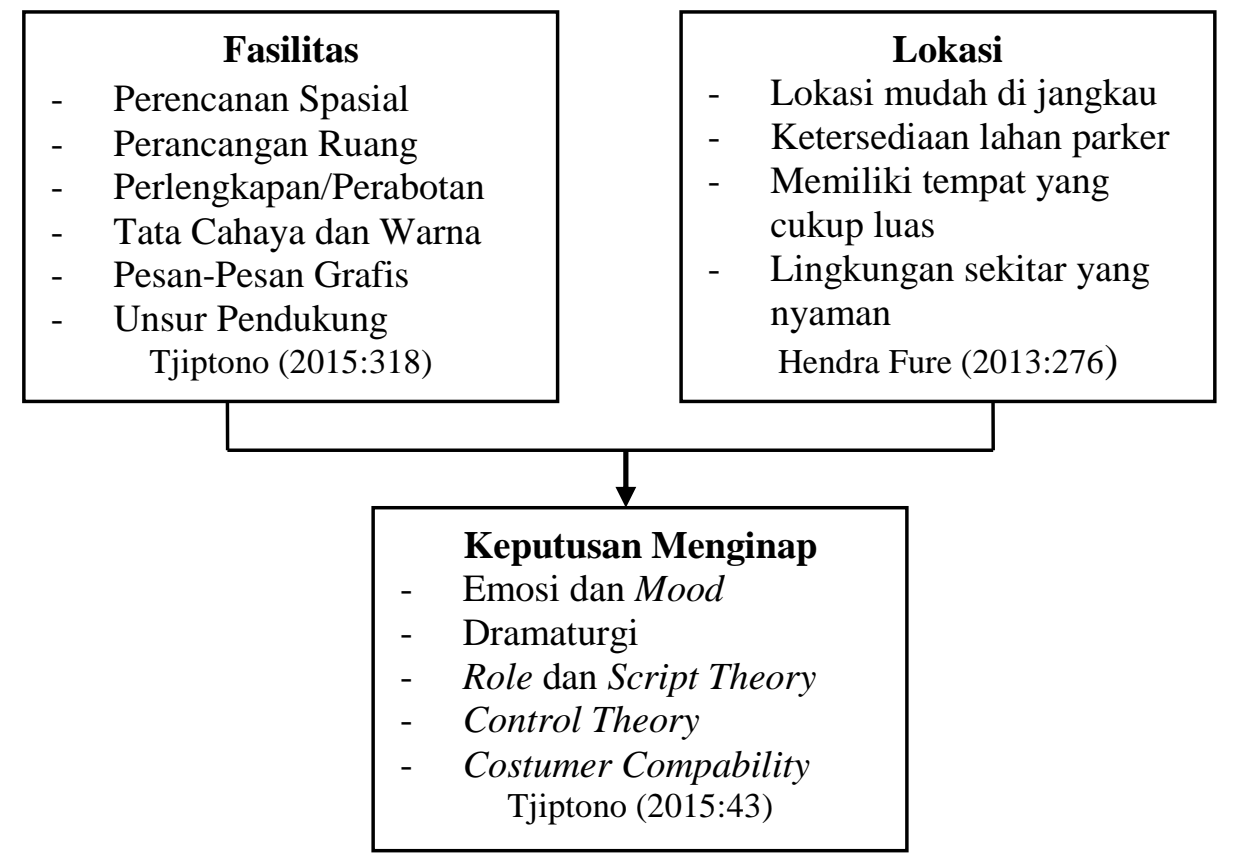

Gambar 1. Kerangka pemikiran

\section{METODE PENELITIAN}

Jenis dan Lokasi Penelitian

Jenis penelitian yang digunakan dalam penelitian ini adalah jenis penelitian kuantitatif. Berdasarkan karakteristik masalah yang diangkat oleh peneliti, maka penelitian ini diklasifikasikan ke dalam penelitian deskriptif kuantitatif. Pada penelitian ini menggambarkan suatu variabel, gejala atau keadaan yang diteliti secara apa adanya 
dengan menggunakan data yang bersifat angka yang diperoleh dari angket atau kuesioner. Lokasi penelitian di Grand Q hotel Kota Gorontalo beralamat di Jalan Nani Wartabone, Ipilo Kota Gorontalo.

\section{Definisi Operasional}

Fasilitas yang dimaksud dalam penelitian ini merupakan segala sesuatu yang bersifat peralatan fisik yang disediakan oleh pihak penjual jasa untuk mendukung kenyamanan konsumen yang meliputi: perlengkapan/perabotan, tata cahaya/warna, pesan-pesan grafis, dan unsur pendukung.

Lokasi yang dimaksud dalam penelitian ini adalah mengacu pada berbagai aktivitas pemasaran yang berusaha memperlancar dan mempermudah penyampaian atau penyaluran barang dan jasa dari produsen kepada konsumen yang meliputi: lokasi mudah dijangkau, ketersediaan lahan parkir, memiliki tempat yang cukup luas, lingkungan sekitar yang nyaman.

Keputusan menginap yang dimaksud dalam penelitian ini adalah merupakan sebuah proses dimana konsumen melalui sebuah tahapan-tahapan guna memperoleh keputusan yang tepat untuk melakukan pembelian yang meliputi:Emosi dan Mood, Dramagturi, Role dan Script Theory, Control Theory, dan Costumer Compability.

\section{Populasi dan Sampel}

Populasi adalah wilayah generalisasi yang terdiri atas Obyek/Subyek yang mempunyai kualitas dan karakteristik tertentu yang ditetapkan oleh peneliti untuk dipelajari dan kemudian ditarik kesimpulannya. Sugiyono (2013:61-62). Dalam penelitian ini, populasi yang digunakan adalah orang yang pernah menginap di Grand Q Hotel Kota Gorontalo. Karena populasi yang digunakan adalah seluruh yang pernah menginap di Grand Q Hotel Kota Gorontalo jumlahnya sangat banyak (tersebar dan sulit diketahui secara pasti), maka dilakukan pengambilan sampel untuk penelitian ini.

Menurut Sugiyono (2015:136) Dalam penelitian kuantitatif, sampel adalah bagian dari jumlah dan karakteristik yang dimiliki oleh populasi tersebut.

Penggunaan teknik sampel yang di pilih adalah penarikan sampel Accidental Sampling yaitu teknik penentuan sampel berdasarkan kebetulan, karateristik responden sebagai berikut: 1). Konsumen yang berusia 20-50 tahun ke atas dan 2). Konsumen yang pernah menginap di Hotel Garnd Q. mengacu pada rumus yang digunakan (Martanti 2006) dalam menentukan besarnya sampel. Hasil perhitungan maka sampel yang di tentukan adalah 96 responden.

\section{Metode Pengumpulan data}

Penelitian ini merupakan penelitian kuantitatif yang dilakukan pada konsumen Grand Q Hotel Kota Gorontalo dengan cara menyebar angket/kusioner penelitian kepada responden yang memenuhi standar sampel yang ditentukan oleh peneliti sebelumnya. Data penelitian yang digunakan dalam penelitian ini merupakan data primer yang diperoleh dengan menggunakan daftar pernyataan (kuisioner) yang telah disebarkan langsung. Jumlah responden yang menjadi subjek penelitian sebanyak 96 responden yang memenuhi standar sampel penelitian. Tingkat pengembalian kuisioner (response rate) dan dapat digunakan (respon use) sebesar 100\%, dihitung dari presentase jumlah kuisioner kembali (96 kuisioner) dibagi total yang dikirim (96 kuisioner). 


\section{Teknik Analisis Data}

Data yang telah terkumpul selanjutnya dioleh dengan menggunakan komputer dengan program SPSS. Pengolahan dan analisa data dilakukan dengan menggunakan analisis regresi linear berganda.

III. HASIL DAN PEMBAHASAN

Hasil

Pengambilan keputusan berdasarkan nilai alpha cronbach jika nilai alpha melebihi atau sama dengan 0,6 maka pernyataan variabel tersebut reliabel dan sebaliknya (Ghozali, 2013). Adapun hasil pengujian reliabilitas masing-masing variabel dapat dilihat sebagai berikut: Pengujian reliabilitas pernyataan tersebut disajikan pada tabel 1 sebagai berikut:

Tabel 1 Hasil Uji Reliabilitas Variabel Fasilitas

\begin{tabular}{ccccc}
\hline Variabel & $\begin{array}{c}\text { Koefisien } \\
\text { Realibilitas }\end{array}$ & $\begin{array}{c}\text { Angka } \\
\text { Acuan }\end{array}$ & Keterangan & Status \\
\hline $\begin{array}{c}\text { Fasilitas } \\
\text { (X2) }\end{array}$ & 0,815 & 0,6 & $\begin{array}{c}\text { Nilai Cronbah Alpa }> \\
0,6\end{array}$ & Reliabel \\
\hline
\end{tabular}

Sumber: Data Olahan SPSS versi 21, 2019

Berdasarkan hasil analisis dengan menggunakan teknik alpha croncbach diperoleh nilai koefisien reliabilitas variabel fasilitas lebih besar dari nilai patokan yang telah ditentukan yaitu $0.6(0,815>0,6)$. Pengujian reliabilitas pernyataan tersebut disajikan pada tabel 2 sebagai berikut:

Tabel 2 Hasil Uji Reliabilitas Variabel Lokasi

\begin{tabular}{ccccc}
\hline Variabel & $\begin{array}{c}\text { Koefisien } \\
\text { Realibilitas }\end{array}$ & $\begin{array}{c}\text { Angka } \\
\text { Acuan }\end{array}$ & Keterangan & Status \\
\hline Lokasi (X3) & 0,794 & 0,6 & Nilai Cronbah Alpa $>0,6$ & Reliabel
\end{tabular}

Sumber: Data Olahan SPSS versi 21, 2019

Berdasarkan hasil analisis dengan menggunakan teknik alpha croncbach diperoleh nilai koefisien reliabilitas variabel lokasi lebih besar dari nilai patokan yang telah ditentukan yaitu $0.6(0,794>0,6)$. Hal ini menunjukan bahwa instrumen dalam penelitian ini reliabel atau dapat dipercaya dan dapat digunakan untuk penelitian selanjutnya. Pengujian reliabilitas pernyataan tersebut disajikan pada tabel 3 sebagai berikut:

Tabel 3 Hasil Uji Reliabilitas Variabel keputusan menginap

\begin{tabular}{ccccc}
\hline Variabel & $\begin{array}{c}\text { Koefisien } \\
\text { Realibilitas }\end{array}$ & $\begin{array}{c}\text { Angka } \\
\text { Acuan }\end{array}$ & Keterangan & Status \\
\hline $\begin{array}{c}\text { Keputusan } \\
\text { Menginap (Y) }\end{array}$ & 0,856 & 0,6 & $\begin{array}{c}\text { Nilai Cronbah Alpa } \\
>0,6\end{array}$ & Reliabel \\
& & & & \\
\hline
\end{tabular}

Sumber: Data Olahan SPSS versi 21, 2019

http://jurnal.stiekma.ac.id/index.php/JAMIN 


\section{Pengujian Asumsi Klasik}

Hasil Normal Probability Plot untuk uji normalitas disajikan dalam gambar 1 berikut:

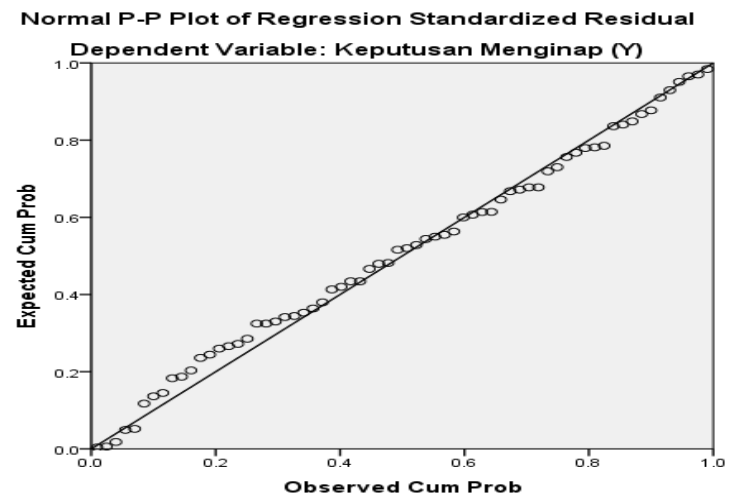

Gambar 2. Grafik Hasil Pengujian Normal Probability Plot Sumber: Data Olahan SPSS versi 21, 2019

Berdasarkan gambar tersebut dapat dilihat bahwa data (titik) menyebar disekitar garis diagonal dan mengikuti arah garis diagonal. Namun untuk memperkuat hasil tersebut maka perlunya dilakukan pengujian Kolmogorov Smirnov. Hasil uji One Sample Kolmogorov Smirnov dapat dijabarkan berikut:

Tabel 4. Hasil Uji Normalitas

\begin{tabular}{|cc|c|}
\hline \multicolumn{2}{|c|}{$\mathrm{N}$} & Unstandardized Residual \\
\hline \multirow{2}{*}{ Normal Parameters ${ }^{\mathrm{a}, \mathrm{b}}$} & Mean & 66 \\
& Std. Deviation & .0000000 \\
Most Extreme Differences & Absolute & 2.41742133 \\
& Positive & .064 \\
& Negative & .046 \\
Test Statistic & -.064 \\
Asymp. Sig. (2-tailed) & .064 \\
\hline
\end{tabular}

Sumber: Pengolahan data SPSS 21, 2019

Berdasarkan tabel di atas dapat dilihat bahwa nilai signifikansi dari residual (galat) regresi sebesar 0,200 sehingga angka ini lebih besar dari 0,05. Untuk itu dapat disimpulkan data dalam penelitian ini memiliki distribusi data yang normal sehingga regresi berganda dapat dilakukan tanpa khawatir terjadinya bias dalam estimasi.

\section{Pengujian Multikolinearitas}

Hasil pengujian asumsi klasik multikolinearitas dengan menggunakan SPSS 21 disajikan sebagai berikut ini: 
Tabel 5. Pengujian Multikolinearitas

\begin{tabular}{|c|c|c|}
\hline \multirow{2}{*}{ Model } & \multicolumn{2}{|c|}{ Collinearity Statistics } \\
\cline { 2 - 3 } & Tolerance & VIF \\
\hline (Constant) & & \\
Fasilitas & .783 & 1.277 \\
Lokasi & .780 & 1.282 \\
\hline
\end{tabular}

Sumber: Pengolahan Data SPSS 21, 2019

Berdasarkan hasil pada tabel 5 diatas terlihat bahwa variabel harga memiliki nilai tolerance sebesar 0,993 dan VIF sebesar 1,007. Fasilitas tolerancenya sebesar 0,783 dan VIF sebesar 1,277.Kemudian lokasi nilainya sebesar 0,780 dan dan VIF sebesar 1,282. Nilai tolerance tersebut lebih besar dari angka standar 0,1 dan nilai VIF kurang dari angka standar 10. Sehingga dalam penelitian ini tidak terjadi gejala multikolinearitas atau memnuhi uji multikolinearitas data penelitian

\section{Pengujian Heterokedastisitas Data}

Gambar 2 berikut merupakan hasil pengolahan data (Scaterplot) untuk menguji heterokedastisitas:

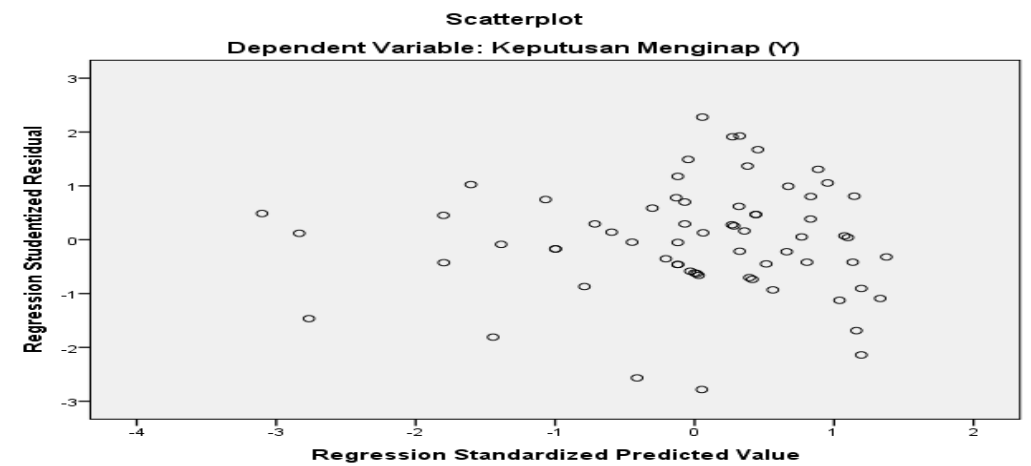

Gambar 3. Hasil Pengujian Heterokedastisitas

Sumber: Data Olahan SPSS versi 21, 2019

Berdasarkan gambar di atas dapat diketahui bahwa titik-titik menyebar secara acak serta tersebar baik di atas maupun di bawah angka nol pada sumbu Y. Oleh karena itu maka dapat disimpulkan bahwa model regresi tidak terjadi heterokedastisitas.

\section{Hasil Analisis Regresi Berganda}

Analisis regresi Berganda digunakan untuk melihat pengaruh beberapa variabel bebas terhadap variabel terikat.Kemudian untuk pengujian signifikansi pengaruh menggunakan uji t.

Sulastiyono (2013) mengatakan bahwa hasil positif atau negatif hanya menunjukan arah bukan menunjukan jumlah.Sehingga dalam interpretasi membandingkan $t_{\text {hitung }}$ dengan $t_{\text {tabel }}$ tidak perlu melihat angka negatifnya sebagai jumlah dari $t_{\text {hitung. Hasil analisis dengan }}$ bantuan program SPSS ditampilkan pada tabel 6 sebagai berikut: 
Tabel 6. Hasil Analisis Regresi

\begin{tabular}{|c|c|c|c|c|c|}
\hline \multirow{2}{*}{ Model } & \multicolumn{2}{|c|}{$\begin{array}{c}\text { Unstandardized } \\
\text { Coefficients }\end{array}$} & \multirow{2}{*}{$\begin{array}{c}\begin{array}{c}\text { Standardized } \\
\text { Coefficients }\end{array} \\
\text { Beta }\end{array}$} & \multirow[t]{2}{*}{$\mathbf{T}$} & \multirow{2}{*}{ Sig. } \\
\hline & B & Std. Error & & & \\
\hline \multirow{3}{*}{$\begin{array}{cc}\text { (Constant) } \\
1 & \text { Fasilitas } \\
& \text { Lokasi } \\
\end{array}$} & 6.236 & 4.377 & & ${ }^{-}$ & .159 \\
\hline & .265 & .087 & .269 & 3.045 & .003 \\
\hline & .828 & .125 & .587 & 6.634 & .000 \\
\hline \multicolumn{6}{|c|}{$\begin{array}{l}{ }^{\mathrm{n}} \text { not significant (Tidak Signifikan) } \\
* \text {. Significant at the } 0.1 \text { level ( } 2 \text {-tailed). } \\
{ }^{* *} \text { Significant at the } 0.05 \text { level ( } 2 \text {-tailed). } \\
* * * \text {. Significant at the } 0.01 \text { level ( } 2 \text {-tailed) }\end{array}$} \\
\hline
\end{tabular}

Sumber: Data olahan SPSS 21, 2019

Berdasarkan hasil analisis di atas, model persamaan regresi linear berganda adalah: $\hat{Y}=$ $6.236+0,374 X_{1}+0,265 X_{2}+0,828 X_{3}+\varepsilon$

\section{Pembahasan}

Pengaruh fasilitas terhadap keputusan menginap di Grand Q Hotel Kota Gorontalo

Fasilitas adalah sarana yang sifatnya mempermudah konsumen untuk melakukan suatu aktivitas. Fasilitas menjadi salah satu pertimbangan konsumen dalam menentukan pilihan. Pada tingkat harga yang hampir sama, Semakin lengkap fasilitas yang disediakan pihak hotel, maka akan semakin puas pelanggan dan ia akan terus memilih perusahaan tersebut sebagi pilihan prioritas berdasarkan persepsi yang ia peroleh terhadap fasilitas yang tersedia.

Berdasarkan hasil analisis ditemukan bahwa fasilitas berpengaruh positip dan signifikan terhadap keputusan menginap di Grand Q hotel Kota Gorontalo, hal ini menunjukkan bahwa semakin baik fasilitas maka akan semakin meningkat keputusan konsumen untuk menginap, sebaliknya apabila fasilatas kurang maka maka menurun keputusan konsumen untuk menginap di Grand $Q$ hotel Kota Gorontalo. Adanya pengaruh yang signifikan menunjukan bahwa konsumen seringkali menjadi ketersediaan dan memadainya fasilitas menjadi dasar bagi konsumen untuk memutuskan menggunakan jasa hotel tersebut atau tidak.

Temuan hasil penelitian ini didukung Caesari dkk (2015), meneliti faktor-faktor yang mempengaruhi konsumen untuk menginap di hotel Puri Saron. Hasil menunjukkan bahwa faktor yang dominan terhadap keputusan menginap di Hotel Puri Saron adalah faktor kualitas pelayanan dan fasilitas. Lopies dkk (2016) menjelaskan bahwa jenis fasilitas kamar hotel berdasarkan tingkatannya yakni: standar room, twin room, double room, dan triple room atau family room. Temuan penelitian ini juga mendukung Tjiptono (2015: 112) Persepsi yang diperoleh dari interaksi pelanggan dengan fasilitas berpengaruh terhadap kualitas jasa tersebut dimata pelanggan. Selanjutnya temuan hasil penelitian ini tidak mendukung Annishia dan Prastiyo (2019) menyatakan bahwa fasilitas tidak berpengaruh signifikan terhadap keputusan konsumen menginap di Hotel Best Western Premier The Hive Jakarta. 
Hasil analisis jawaban responden ditemukan bahwa rata-rata skor untuk variabel fasilitas berada pada kategori yang "baik". Hal ini menunjukan bahwa fasilitas yang tersedia di Grand Q Hotel Kota Gorontalo sudah memadai dan sesuai dengan kebutuhan dari konsumen yang menjadi tamu di hotel tersebut. Kualitas fisik dapat membedakan perusahaan dari para pesaing serta menjadi tanda dari segmen pasar yang dituju Yazid (2009:151). Fasilitas fisik merupakan salah satu indikator mengenai baik tidaknya kualitas suatu jasa dan erat kaitannya dengan pembentukan persepsi pelanggan, dengan adanya fasilitas yang baik maka konsumen akan tertarik dengan jasa yang ditawarkan dan melakukan pembelian jasa yang ditawarkan tersebut. Hasil ini sesuai dengan pernyataan dari Soeprihanto (2009), fasilitas adalah penyediaan perlengkapan-perlengkapan fisik untuk memberikan kemudahan kepada para tamu dalam melaksanakan aktivitas-aktivitasnya atau kegiatan-kegiatannya, sehingga kebutuhan-kebutuhan tamu dapat terpenuhi selama tinggal dihotel.

\section{Pengaruh lokasi terhadap keputusan menginap di Grand Q Hotel Kota Gorontalo}

Hasil analisis penelitian ditemukan bahwa lokasi berpengaruh positif namun tidak signifikan terhadap keputusan menginap di Grand Q Hotel Kota Gorontalo. Hal ini menunjukkan bahwa semakin strategis lokasi, maka akan semakin tinggi pula keinginan konsumen untuk menginap di Grand Q Hotel Kota Gorontalo. Hasil yang tidak signifikan ini karena lokasi dari Grand Q Hotel yang strategis namun ada pertimbangan parkir yang kadangkala menyurutkan niat dari konsumen untuk menginap di Hotel tersebut.

Temuan penelitian ini sesuai dengan pernyataan dari Buchari (2008: 160) bahwa lokasi sangat strategis dan mudah dijangkau, dekat dengan pusat keramaian sehingga mudah melakukan aktivitas, lokasi parkir yang memadai dan luas, mudah dijangkau oleh sarana transportasi, dengan demikian semakin tinggi lokasi maka keputusan pembelian juga semakin meningkat. Mambruroh (2016),menyatakan bahwa harga, kualitas pelayanan, dan lokasi berpengaruh signifikan terhadap keputusan menginap di hotel syariah Surakarta.

Lokasi merupakan tempat dari suatu usaha dilakukan oleh pemiliknya. Menurut Soeprihanto (2009: 103) letak atau lokasi perusahaan sering disebut sebagai tempat kegiatan perusahaan melakukan kegiatan sehari-hari. Mayoritas dari para pengguna jasa hotel adalah mereka yang berasal dari luar daerah yang sedang memiliki urusan disekitar hotel itu berada baik untuk tujuan wisata, bisnis ataupun hanya sebagai tempat transit sementara untuk kemudian melanjutkan perjalanan mereka. Menurut Heizer (2001) lokasi mempunyai kekuatan utuk mensukseskan ataupun menghancurkan strategi perusahaan.

Lokasi Grand Q Hotel yang strategis dan berada di pusat kota juga dekat dengan instansi dan pusat perbelanjaan serta mudah di jangkau memudahkan bagi para konsumen untuk beraktivitas. Hasil analisis deskriptif variabel lokasi ditemukan bahwa rata-rata skor berada pada kategori yang baik. Hal ini menunjukan bahwa konsumen Grand Q Hotel Kota Gorontalo merasakan bahwa lokasi dari hotel berada pada lokasi yang strategis karena di pusat Kota dan dekat dengan berbagai instansi dan pusat perbelanjaan. Meski demikian, sebagian besar konsumen merasakan bahwa Grand Q Hotel Kota Gorontalo kurang representatif untuk lokasi parkirnya, selain karena jalan menuju parkir yang curam dan juga pengunjung yang akan parkir di jalan depan hotel akan mengganggu lalu lintas. 
Pengaruh Fasilitas, dan lokasi terhadap keputusan menginap di Grand Q Hotel Kota Gorontalo

Hasil analisis ditemukan bahwa secara simultan fasilitas dan lokasi berpengaruh signifikan terhadap keputusan menginap di Grand Q Hotel Kota Gorontalo. Hasil yang signifikan ini menunjukan bahwa semakin optimal fasilitas dan lokasi, maka akan mendorong tingginya keputusan konsumen dalam menginap di Grand Q Hotel Kota Gorontalo. Temuan penelitian ini mendukung Pristanto dkk (2012), menyatakan bahwa fasilitas dan lokasi berpengaruh signifikan terhadap keputusan menginap pada Hotel Bintang Mulia Jember. Menurut Payne (2014) pemasaran jasa merupakan proses mempersepsikan, memahami, menstimulasi dan memenuhi kebutuhan pasar sasaran yang dipilih secara khusus dengan menyalurkan sumbersumber sebuah organisasi untuk memenuhi kebutuhan tersebut.

Temuan penelitian ini juga mendukung Castro (2018), menyatakan bahwa lokasi dan fasilitas berpengaruh positif dan signifikan terhadap keputusan konsumen menginap di hotel. Emosi dan mood konsumen sangat mempengaruhi terhadap semua tahap keputusan menginap konsumen untuk itu pelayanan dari penyedia jasa harus optimal agar mampu mempengaruhi emosi dan mood konsumen karena ini sangat berpengaruh terhadap keputusan konsumen untuk menentukan keputusan menginap.

Hasil pengujian deskriptif untuk variabel keputusan menginap ditemukan bahwa rata-rata keputusan menginap konsumen di Grand Q Hotel Kota Gorontalo berada pada kategori yang baik. Hal ini menunjukan bahwa konsumen Grand Q Hotel Kota Gorontalo memiliki preferensi yang tinggi dalam menggunakan Grand Q Hotel Kota Gorontalo sebagai tujuan untuk menginap.Tingginya animo masyarakat ini tentunya dikarenakan berbagai keunggulan dari hotel yang tertuang dalam suatu strategi melalui bauran pemasaran yang semakin maksimal seperti tarif yang bersaing, fasilitas yang baik sebagai representasi dari kualitas hotel serta lokasi yang strategis. Kotler dan Amstrong, (2013) menyatakan bahwa sebagai upaya untuk meningkatkan loyalitas konsumen sebagai inti dari keputusan menginap maka perlunya untuk memberikan kesan yang baik kepada konsumen dengan memaksimalkan harga, fasilitas dan lokasi yang masih belum sepenuhnya optimal di Grand Q Hotel Kota Gorontalo.

\section{KESIMPULAN}

1. Fasilitas berpengaruh positif dan signifikan terhadap keputusan menginap. Hal ini menunjukkan bahwa semakin memadai fasilitas dari hotel, maka konsumen akan semakin tertarik untuk memutuskan menginap di Grand Q Hotel Kota Gorontalo.

2. Lokasi berpengaruh positif namun tidak signifikan terhadap keputusan menginap. Nilai positif menunjukkan bahwa semakin strategis lokasi dari Grand Q Hotel Kota Gorontalo maka akan semakin tinggi pula keinginan konsumen untuk menginap di Grand Q Hotel Kota Gorontalo. Hal yang menyebabkan pengaruh tidak signifikan karena masalah parkir hotel yang tidak luas.

3. Fasilitas, dan lokasi secara bersama-sama berpengaruh signifikan terhadap keputusan menginap di Grand Q Hotel Kota Gorontalo dengan nilai determinan sebesar $60,00 \%$. Sisanya sebesar $40,00 \%$ dapat dijelaskan oleh variabel lain yang tidak diteliti dalam penelitian seperti promosi dan kualitas pelayanan. 
VI. Saran:

1. Sebaiknya manajemen hotel senantiasa memperhatikan fasilitas hotel karena sebagian masyarakat pengunjung merasakan bahwa fasilitas yang tersedia masih perlu untuk dibenahi, ditambah dan bahkan ada yang harus diperbaiki oleh pihak manajemen hotel.

2. Pentingnya lokasi parkir yang luas dan pengaturan tempat parkir bagi pengunjung hotel karena alasan parkir menjadi salah satu alasan yang membuat masyarakat enggan untuk menginap di Grand Q Hotel Kota Gorontalo. Selanjutnya sebagai upaya untuk meningkatkan loyalitas konsumen sebagai inti dari keputusan menginap maka perlunya untuk memberikan kesan yang baik kepada tamu hotel.

\section{DAFTAR PUSTAKA}

Annishia, Fristi dan Prastiyo, eko, 2019. Pengaruh Harga dan Fasilitas Terhadap Keputusan Menginap Tamu Di Hotel Best Western Premier The Hive Jakarta. Jurnal hospitality dan pariwisata. (online). Vol.4. No.1. Januari 2019 pp:1-85. (http://journal.ubm.ac.id diakses 19 oktober 2019)

Buchari, Alma, (2008), Manajemen Pemasaran Dan Pemasaran Jasa. Bandung, Alfabeta

Caesari, Septia, dkk, 2015. Analisi Faktor Faktor Yang Mempengaruhi Konsumen Untuk Menginap Di Hotel Puri Saron. Journal Of Social And Political Of Sience. (online) 2015 pp:1-11. (http://ejournal-s1.undip.ac.id/index.php diakses 19 oktober 2019)

Castro, Conceciao 2018. Online hotel ratings and its influence on hotel room rates: the case of Lisbon, Portugal. Journal Tourism \& Management , (online) PP:63-72 (https://www.researchgate.net/publication/ diakses 19 oktober 2019)

Ghozali, Imam. 2013. Aplikasi Analisis Multivariate Dengan Program SPSS. Yogyakarta

Heizer, Jay, (2001), Prinsip-Prinsip Manajemen Oprasi, Operations Manajement, Jakarta, Selemba Empat

Hendra Fure, 2013, Lokasi, Keberagaman Produk, Harga dan Kualitas Pelayanan Pengaruhnya Terhadap Minat Beli Pada Pasar Tradisional Bersehati Celaca, Jurnal EMBA,(online). 2013. Vil.1 No.3. (https://ejournal.unsrat.ac.id diakses 19 oktober 2019)

Lopies, Alfredo, dkk. 2016. Analisa Faktor Faktor Yang Mempengaruhi Konsumen Dalam Memutusakan Untuk Menginap Di Green Hotel Di Surabaya. Jurnal hospitality dan pariwisata. (online) Vol.2 No.4.(http://journal.ubm.ac.id diakses 19 oktober 2019)

Kotler, Philip and Amstrong Gery, 2013, Prinsip-Prinsip Pemasaran, Edisi 12, : Erlangga

Kotler, Philip and Keller, Lane Kevin, 2016, Marketing Management, $15^{\text {th }}$ Edition New Jersey : Person Pretice Hal, inc.

Martanti, 2006, Metode Penelitian, BPFE, Yogyakarta

Mambruroh (2016), analisis keputusan menginap di hotel syariah berdasarkan harga kualitas pelayanan dan lokasi pada pelanggan hotel syariah di surakarta, Jurnal Of Management (online). 2016 
Mimi SA, 2015, Pengaruh Harga, Kualitas Pelayanan, Lokasi dan Keragaman Produk Terhadap Keputusan Pembelian Di Ranch Market, Jurnal Ekonomi (online) 2015. Voll.22 No.1 (https://ecojoin.org/index. diakses 19 oktober 2019)

Pristanto dkk, 2012. Analisis Faktor Faktor Yang Mempengaruhii Keputusan Menginap Pada Hotel Bintang Mulia Jember. Jurnal EMBA (online). 2012 pp:1-6. (http://repository.unej.ac.iddiakses 19 oktober 2019)

Payne, Adrian, (2014), Pemasaran Jasa, The Essense Of Service Marketing , Andi Yogyakarta.

Soeprihanto, 2009, Pengantar Bisnis : Dasar Dasar Sumber Daya Perusahaan, Edisi 5, Liberty

Sugiyono. 2013. Metode Penelitian Pendidikan Pendekatan Kuantitatif, Kualitatif Dan R\&D. Alfabeta, Bandung

Sugiyono. 2015. Metode Penelitian Pendidikan Pendekatan Kuantitatif, Kualitatif Dan R\&D. Alfabeta, Bandung

Sulastiyono, Agus, 2013, Manajemen Penyelenggaraan Hotel, Alfabeta, Bandung

Tjiptono, Fandy, 2014, Pemasaran Jasa (Prinsip, Penerapan, Penelitian), Yogyakarta : Andi Offset.

------, Fandy, 2015, Strategi Pemasaran, Edisi 4, Andi, Yogyakarta

Yazid, (2009), Pemasaran Jasa Konsep DanImplementasi, Ekonisia, Yogyakarta 